Vol. 2, No. 2, 2020

https://doi.org/10.23939/jtbp2020.02.035

Iryna Hornikovska, Vadym Kahanov

\title{
NON-AUTOCLAVED FOAM CONCRETE FOR LAYERS OF HIGHWAYS SURFACE DRESSING
}

\author{
Lviv Polytechnic National University, \\ Department of building production, \\ hornikovska@gmail.com
}

(C) Hornikovska I., Kahanov V., 2020

The article is devoted to the problems associated freeze with the calculated estimation of the parameters of the structural and heat-insulating antifreeze layer in the subgrade of non-rigid roads on various soil bases. The main physical, technical and deformation characteristics of monolithic dispersed non-autoclaved foam concrete reinforced with polypropylene fiber of grades of density from 600 to $1000 \mathrm{~kg} / \mathrm{m}^{3}$ are investigated.

Freezing of subsoil waters directly under the roadway pavement and, as a result, its increase in volume, leads to significant deformations of the road surface. Under such conditions, the period of defectfree operation of the roadway pavement is significantly reduced, which in turn leads to the need to repair it in a more intensive mode.

One of the ways to reduce the operating cost and maintenance costs of the road transport infrastructure is to introduce into the design and construction practice new structural concepts for road surface dressing that ensure high quality pavement during the normative operational period. This can be achieved by introducing an effective heat-insulating material into the pavement structure as an anti-frost layer in order to elimi-nate the effect of frost lift of the roadway pavement of non-rigid roads.

Since domestic and foreign experience freeze in the road construction has proven the effectiveness of the use of heatinsulating materials in the road surface dressing construction, in recent years in Ukraine there has been increased interest in the use of non-autoclaved foam concrete as a modern and highly effective heat-insulating material in road construction.

The installation of a heat-insulating layer made of non-autoclaved foam concrete allows us to completely or partially prevent freezing or overheating of the surface dressing base, reduce the influence of periodic variations in environmental temperature, which in turn will increase the durability of the pavement structure. The publication presents nomograms for determining the optimal thickness of the heat-insulating anti-frost heavy course (layer) of road surface dressing (based on sand, loamy sand, clay and loam) done at the street and road network for all climatic and geographical regions of Ukraine.

Key words: non-autoclaved foam concrete, anti-frost heavy course (layer), highways surface dressing, frost lift.

\section{Introduction}

In the context of an ever-growing traffic load, an increase in the intensity and speed of movement on highways increases the cost of general overhaul and current repairs of roads to ensure traffic safety on them. If we compare the durability of road surface dressing at domestic and foreign facilities of transport infrastructure, then in Ukraine there is a 1.5-2.0 times shorter period between overhauls (or current repairs) under almost identical climatic service conditions. In addition, the calculation standards and the 
quality of pavement performance in Ukraine and other countries (incl. the European Union) have certain differences. The types and properties of road building materials used in the construction and design of roads are also different.

One of the ways to reduce the operating cost and maintenance costs of the road transport infrastructure is to introduce into the design and construction practice new structural concepts for road surface dressing that ensure high quality pavement during the normative operational period. This can be achieved by introducing an effective heat-insulating material into the pavement structure as an anti-frost layer in order to eliminate the effect of frost lift of the roadway pavement of non-rigid roads.

Freezing of subsoil waters directly under the roadway pavement and, as a result, its increase in volume, leads to significant deformations of the road surface. Under such conditions, the period of defectfree operation of the roadway pavement is significantly reduced, which in turn leads to the need to repair it in a more intensive mode.

Foam concrete is a versatile and effective heat insulating material that has been widely and long used in civil and industrial construction in Ukraine and abroad. The installation of a heat-insulating layer made of non-autoclaved foam concrete allows us to completely or partially prevent freezing or overheating of the surface dressing base, reduce the influence of periodic variations in environmental temperature, which in turn will increase the durability of the pavement structure.

\section{Target of this article}

The article is devoted to the problems associated with the calculated estimation of the parameters of the structural and heat-insulating antifreeze layer in the subgrade of non-rigid roads on various soil bases.

\section{Analysis of recent research and publications}

Currently, in Ukraine, in the roads-and-highways construction, an anti-frost heavy course (layer) is used, which is made of coarse-grained and average-grained sands (up to $95 \%$ ) and laid under monolithic concrete and asphalt concrete pavement done on a concrete basis. However, such constructive solutions do not allow reliable protection of the surface dressing structure from winter heaving and lift, which affects the quality of its pavement and operational characteristics.

Foreign experience in the road construction (Kadela, 2017) has shown the effectiveness of heat insulating materials use in the road surface dressing construction. Research and application of various heat-insulating materials in road construction began in the middle of the twentieth century, since the problem of reducing the freezing of the subgrade of pavement is important not only for Ukrainian roads.

Since domestic and foreign experience in the road construction has proven the effectiveness of the use of heat-insulating materials in the road surface dressing construction, in recent years in Ukraine there has been increased interest in the use of non-autoclaved foam concrete as a modern and highly effective heat-insulating material in road construction.

Most researchers of dispersed concrete reinforcement paid attention to its in-creased strength characteristics compared to unreinforced concrete (Verba, 2012; Fedorowicz, 2014; Doroshenko, 2006; Pukharenko, 2006; Martynenko, 2002; Namsone, 2017; Kahanov, 2010; Fukang 2013). However, cement concretes may have low stress-related properties, including crack resistance and a high degree of weakness to destruction.

\section{Result and discussion}

Despite the fact that building materials in the road surface dressing construction are laid according to their stress reduction coefficient in conformity with the attenuation of live-load stress, the critical data 
of the stress-strain state according to the crite-ria of fracture mechanics should be determined both for concrete, used for pave-ment, and for foam concrete, used at heat-insulating (anti-freeze) layer.

Studies of the deformation characteristics of foam concrete reinforced with polypropylene fiber fibers, including crack resistance studies, showed the possibility of using foam concrete as a heatinsulating (anti-frosty) layer in the construction of road pavement of roads (Solodkyy, 2015). The nature of the deformations of foam concrete reinforced with polypropylene fiber differs from the samples under study, in which dispersed fibers were not used. The peak value of fiber-reinforced foam concrete deformations under load to the critical point of failure is 4.7-5.7 times higher than the deformation of non-reinforced foam concrete.

The main effect of introducing polypropylene fiber into the composition of foam concrete is observed in the supercritical fracture stage, when the fiber restrains the process of fracture of the samples from the moment of the development of the main crack (from the moment when the maximum crushing load is applied) and to its full fragmentation, which ensures the stability of the developed concrete under extreme loads.

The proposed approaches to designing and calculating the non-rigid road surface dressing construction are based on eliminating frost lift of the road pavement, but not on ensuring its acceptable value (Kahanov, 2018).

The calculation of the frost resistance of road surface dressing structure given in the current building codes of Ukraine aims to ensure the necessary pavement endurance against loss of stability in the course of uneven swelling of the soil of the road subgrade, that is, to prevent the deformations caused by the frost lift that can exceed the maximum permissible design parameters (Transport facilities. Highways. Part I. Design. Part II. Construction. DBN, 2015; Roads. Non-rigid road dressing. GBN, 2019). But such a calculation algorithm does not take into account the actual thermal and physical characteristics of the building materials used in the construction of road surface dressing. On the other hand, when using the practical methods recommended by the article authors, it is possible to use the equivalent of the thermal and technical properties of road surface dressing materials in the calculation. The calculation method used now is obsolescent and ineffective because it does not reflect the real thermal and physical characteristics of the latest building and road materials that can be used to install the heat-insulating layer of surface dressing in modern design solutions for roads.

The methodology for calculating the parameters of installing an effective heat-insulating layer of road surface dressing, which would take into account the actual thermal conductivity of all layers of pavement and exclude the effect of frost lift of the roadway, is currently absent in modern road design and construction practice in Ukraine. In this regard, the problem of developing foam concrete with enhanced operational properties as an effective heat-insulating layer for the design of durable multilayer surface dressing structures is practically significant and relevant.

The authors developed a methodology for increasing the durability of road surface dressing and eliminating the influence of frost lift on the durability of the non-rigid road pavement by introducing the calculated value of the effective heat-insulating layer into the dressing construction. It is proposed an algorithm for calculating the value of the heat-insulating layer using monolithic foam concrete reinforced with polypropylene fiber, and nomograms for determining the required thickness of the heat-insulating layer made of monolithic structural and heat-insulating fiber-reinforced foam concrete for various soils of road bases.

In order to achieve stability of the surface dressing structure against freeze swelling, it is necessary to provide a stable plus temperature in the basis of the soil of the subgrade under the pavement, which guarantees the avoidance of freezing water in the soil and subsequent formation of ice crystals, which, increasing in volume, cause the process of winter lift. The road surface dressing (in which an insulating foam concrete layer was used) will remain smooth throughout the whole year that will significantly improve the quality of the road surface. 
In order to protect the road surface dressing structure from the effects of winter heaving, the heat flux passing through this road structure should be equal to or less than the heat flux that passes through the soil mass to the level of freezing depth. According to the results of mathematical calculations based on the obtained analytical dependence and the derived average calculated values, there were obtained the values of the necessary thermal resistance of heat transfer for the road surface dressing constructions which are located in a particular climatic region of Ukraine in conformance with the National Standards of Ukraine (DSTU N B V.1.1 -27:2010) (Table 1).

Table 1

\section{Calculated thermal resistance of the road surface dressing construction}

\begin{tabular}{|c|c|c|c|c|}
\hline \multirow{2}{*}{ Climatic region } & $\begin{array}{c}\text { Depth of soil freezing, } \\
\mathrm{H}_{\text {frz }}, \mathrm{cm}\end{array}$ & \multicolumn{3}{|c|}{$\begin{array}{c}\text { The minimum required value of the thermal resistanceof the road } \\
\text { structure (Rneeded) }\end{array}$} \\
\cline { 2 - 5 } & 165 & sand & loamy sand & clay and loam \\
\cline { 2 - 5 } & 150 & 1.054 & 1.455 & 1.598 \\
\hline I & 130 & 0.958 & 1.323 & 1.453 \\
\hline II & 110 & 0.843 & 1.164 & 1.279 \\
\hline III(A) & 95 & 0.714 & 0.985 & 1.082 \\
\hline & 80 & 0.628 & 0.867 & 0.952 \\
\hline III(B ) & 95 & 0.529 & 0.730 & 0.801 \\
\hline IV & 80 & 0.642 & 0.886 & 0.973 \\
\hline IV & 95 & 0.541 & 0.746 & 0.820 \\
\hline & 80 & 0.650 & 0.898 & 0.986 \\
\hline & 95 & 0.548 & 0.756 & 0.831 \\
\hline
\end{tabular}

In order to simplify the calculations for the selection of the value of the heat-insulating layer of monolithic fiber-reinforced foam concrete, there were proposed the nomograms for the three main options for the subgrade base (Fig. 1).

The algorithm of nomograms proposed by the article authors for the practical selection of the optimal calculated value of heat-insulating fiber-reinforced foam concrete with a density of 600 to $1000 \mathrm{~kg} / \mathrm{m}^{3}$ makes it possible to create the effective design of an anti-frost heavy course (layer) of nonrigid roads for various soils of a road basis.

The test output introduction of the antifreeze layer in the construction of road surface dressing with structural and heat-insulating dispersed foam concrete reinforced with polypropylene fiber was carried out in the process of the construction of access and intra-quarter roads and pedestrian areas by the Building Contractor "Trembita", Balmiks LLC, Housing Complex "Uman House" while the improvement of the following construction projects, namely: the cottage town "Soniachna Poliana" ("Sunny Park"); the Housing Community "Sonechko" ("Sun"); multi-apartment residential building in Uman city; overhaul of the township road section on the Pivkolo street in the city of Lviv.

Industrial testing of frost-resistant interlayers of foam concrete was carried out during the construction of pilot industrial sections of roads in the Odessa region by the State Enterprise "M.P. Shulgin State Road Research Institute" ("DerzhdorNDI" SE). The results of observations, monitoring and quality control of the road surface dressing of these sections over the past seven years indicate the high efficiency of the use of foam concrete as an anti-frosty layer of pavement of non-rigid roads.

The technology for the installation of a frost-resistant layer made of non-autoclave foam concrete reinforced with polypropylene fiber in the surface dressing structure of highways, intra-quarter driveways and pedestrian foot paths, provides for the mandatory installation of waterproofing layers (geotextile, waterproofing layer or membrane) in order to ensure the necessary moisture content of this material. 
The results of this study were used by the State Enterprise "M.P. Shulgin State Road Research Institute" ("DerzhdorNDI" SE) in the development of "Recommendations for the use of foam concrete in road construction" (P B.2.7-218-03450778-681-2007).
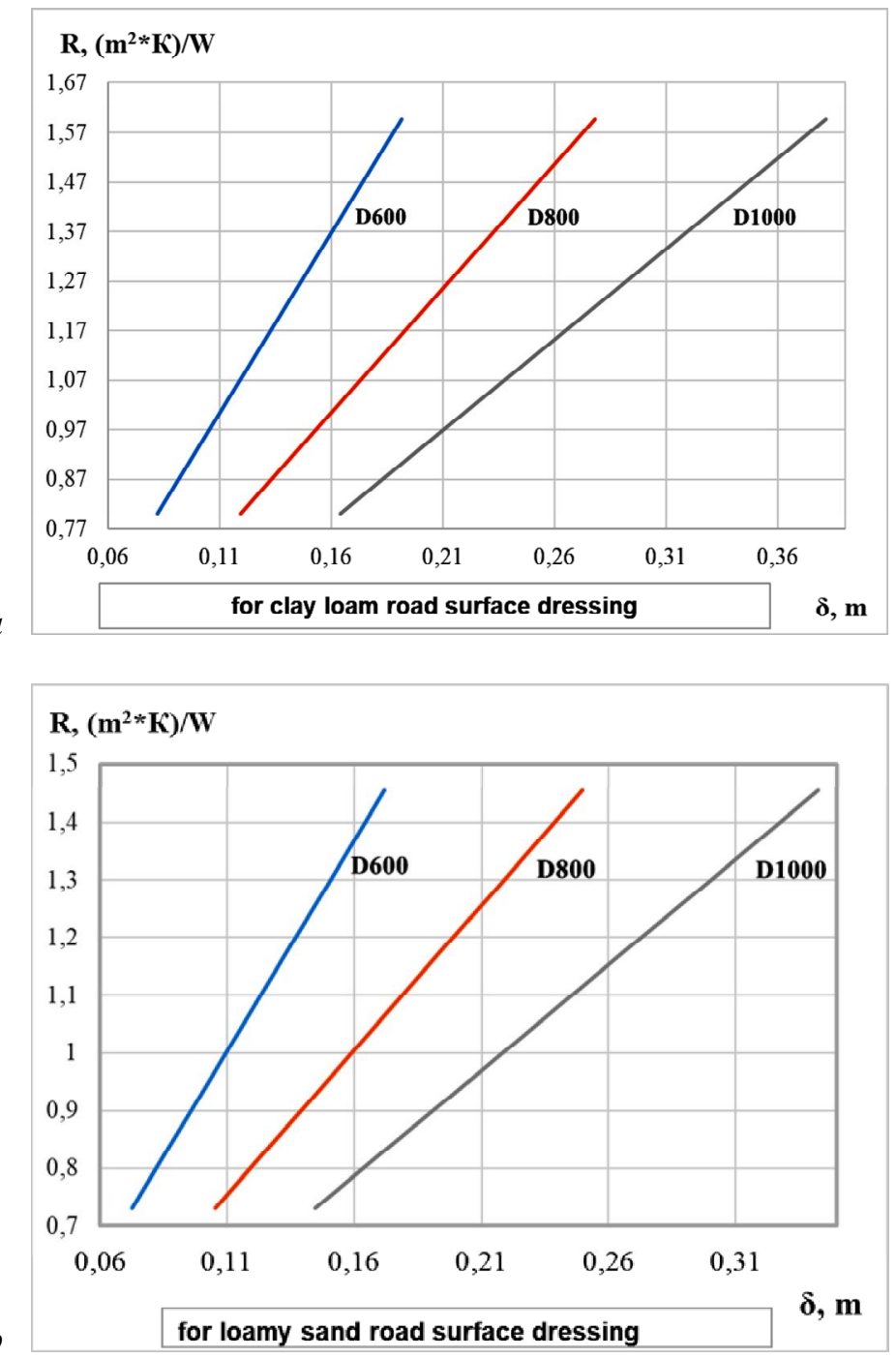

$b$

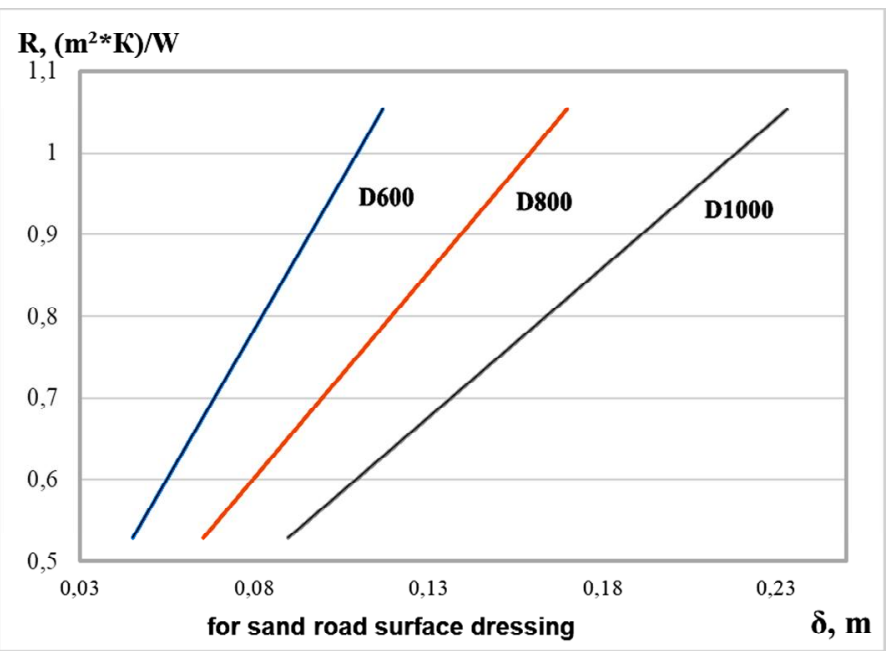

Fig. 1. Nomograms for the selection of the optimal calculated value of heat-insulating foam concrete on the base of clay and loam (a) loamy sand (b); (c) sand 
Industrial approbation of the dissertation results was also carried out in collaboration with the Research and Project Institute of Transport Engineering "KYIVDIPROTRANS" in the process of developing constructive solutions for adjoining the "soft entry" type at the point of transition from the subgrade (crushed stone base) to the upper structure of the railway track to artificial concrete access road constructions at the objects of the "Epicenter" shopping center (1Б, Kiltseva Doroha, Kyiv city) and the production base of the State Enterprise Kyiv Department of Mechanization and Construction under the Ministry of Defense of Ukraine (181, Boryspilska St., Kyiv city).

\section{Conclusion}

The main effect of the introduction of the anti-freeze layer of the required size made of a monolithic non-autoclaved fiber-reinforced foam concrete is an increase of 2.5 times the overhaul cycle during the operation of non-rigid roads.

The algorithm presented in this article for the selection of the effective value of the heat-insulating layer made of non-autoclaved fiber-reinforced foam concrete as a way to prevent frost heaving in surface dressing creates effective opportunities for improving the quality of the street-crossing network in Ukraine and lays the foundation for saving significant material and financial resources during the operation of roads.

\section{References}

Kadela M., Kozłowski M., Kukiełka A. (2017). Application of Foamed Concrete in Road Pavement - Weak Soil System. Procedia Engineering. No. 193. pp. 439-446.

Verba V., Hornikovska I., Demchyna K., Volotsiuha V., Holyk V. (2012). The relationship of strength and deformation characteristics of non-autoclaved foam concrete. Bulletin of the Donetsk National Academy of Civil Engineering and Architecture "Modern Industrial and Civil Engineering", Book No. 8, Issue No. 1, pp. 28-35

Fedorowicz L., Kadela M., Bednarski Ł. (2014). Modeling foam concrete behavior in layered constructions cooperating with the subsoil. Scientific notebooks of the technical school in Katowice, Issue No. 6. pp. 73-81.

Doroshenko O., Doroshenko Yu., Chyzhenko N. (2006). Fiber concrete as an effective mate-rial for transport construction. Journal "Road Transporter and Road Constructor of Ukraine", Issue No. 6, pp. 29-32.

Pukharenko Yu. (2006). Properties and prospects of the use of cellular fiber-reinforced con-crete. Popular Concrete Science, St. Petersburg, Issue No. 4, pp. 50-53.

Martynenko V. (2002). The influence of technological parameters on the properties of insulat-ing foam concrete. Bulletin of the Prydniprovska State Academy of Civil Engineering and Architec-ture, Issue No. 5, pp. 4150 .

Namsone E., Šahmenko G., Korjakins A. (2017). Durability Properties of High Performance Foamed Concrete. Procedia Engineering, Vol. 172. pp. 760-767.

Kahanov V., Hornikovska I., Ivasiv I. (2010). Operational characteristics of the anti-frost heavy course (layer) of non-rigid road surface dressing made of monolithic non-autoclaved foam con-crete. Construction Materials and Products, Issue No. 3, pp. 21-23.

Fukang D. (2013). Mechanical properties and energy-saving effect of polypropylene fiber foam concrete. Research Journal of Applied Sciences, Engineering and Technology. Vol. 6. No. 11. pp. 2012-2018.

Solodkyy S., Kahanov V., Hornikovska I., Turba Y. (2015). A study of fracture touchness of heavy-weight concrete and foam concrete reinforced by polypropylene fiber for road construction. Eastern-European Journal of Enterprise Technologies. No. 4/5 (76), pp. 40-46. ISSN 1729-3774, Scopus.

Kahanov V., Hornikovska I., Pozniak O. (2018). Improving the operational properties of road surface dressing. Collection of abstracts of the International Conference "Structuring, strength and destruction of composite building materials and structures", pp. 20-22, Odesa.

Transport facilities. Highways. Part I. Design. Part II. Construction. DBN B.2.3-4:2015 State Building Codes of Ukraine. (2015). Kyiv: Ministry of Regional Development of Ukraine.

Roads. Non-rigid road dressing. GBN B.2.3-37641918-559:2019. State Building Codes of Ukraine. (2019). Kyiv: Ministry of Infrastructure of Ukraine 
І. Б. Горніковська, В. О. Каганов

Національний університет “Львівська політехніка", кафедра будівельного виробництва

\section{НЕАВТОКЛАВНИЙ ПІНОБЕТОН ДЛЯ ШАРІВ ДОРОЖНІХ ОДЯГІВ АВТОМОБІЛЬНИХ ДОРІГ}

(C) Горніковська I. Б., Каганов В. О., 2020

Стаття присвячена проблематиці, пов'язаній із розрахунковою оцінкою параметрів конструкційно-теплоізоляційного протиморозного прошарку в земляному полотні автомобільних доріг нежорсткого типу на різних грунтових основах. У роботі досліджено основні фізико-технічні та деформативні характеристики монолітного пінобетону неавтоклавного тверднення дисперсно-армованого волокнами поліпропіленової фібри густиною від 600 до 1000 кг/м³

Замерзання грунтових вод безпосередньо під дорожнім полотном і, як наслідок, збільшення їх в об'ємі, призводить до значних деформацій дорожнього покриття. За таких умов термін бездефектної експлуатації дорожнього полотна значно скорочується, що, своєю чергою, призводить до необхідності їх ремонтувати в інтенсивнішому режимі.

Одним із шляхів зниження вартості експлуатації та витрат на утримання дорожньо-транспортної інфраструктури $є$ впровадження в проєктну та будівельну практику нових конструктивних рішень дорожнього одягу, які б забезпечували високу якість дорожнього покриття протягом нормативного експлуатаційно-го періоду. Цього можна досягнути за рахунок введення в конструкцію дорожнього одягу в якості протиморозного прошарку ефективного теплоізоляційного матеріалу з метою запобігання ефекту морозного здимання дорожнього полотна автомобільних доріг нежорсткого типу.

Вітчизняний та закордонний досвід будівництва автомобільних доріг довів ефективність застосування теплоізоляційних матеріалів у конструкції дорожнього одягу, тому в останні роки в Україні 3'явився підвищений інтерес до використання безавтоклавного пінобетону як сучасного та високоефективного теплоізоляційного матеріалу в дорожньому будівництві.

Влаштування теплоізоляційного прошарку з неавтоклавного пінобетону дає змогу повністю або частково запобігти промерзанню або перегрівання основи дорожнього одягу, знизити вплив періодичних температур-них коливань навколишнього середовища, що забезпечує підвищення довговічності конструкції дорожнього полотна. В публікації представлено номограми для визначення оптимальної товщини теплоізоляційного морозозахисного шару дорожніх одягів автомобільних доріг для піску, супіску, глини та суглинку в основі вулично-проїжджої мережі для усіх кліматично-географічних районів України.

Ключові слова: пінобетон неавтоклавного тверднення, протиморозний прошарок, дорожній одяг автомобільних доріг, морозне здимання. 